УДК 4414

\title{
РОЛЬ И ОТВЕТСТВЕННОСТЬ НЕЗАВИСИМЫХ ДИРЕКТОРОВ В СИСТЕМЕ КОРПОРАТИВНОГО УПРАВЛЕНИЯ
}

\author{
Галынина Лидия Ивановна \\ студент \\ Научный руководитель: Бибиков Александр Иванович \\ д.ю.н., профессор \\ ФГБОУ ВО «Ивановский \\ Государственный университет»
}

\begin{abstract}
Аннотация: B статье предпринята попытка анализа проблем корпоративного управления, образовавшихся в связи с тем, что за два десятилетия, и до настоящего периода у граждан создалось впечатление, что управленческие решения и мошенничество внутри компании могут быть устранены с помощью привлечения независимых директоров. Однако прецеденты в корпоративной практике по всему миру не подтверждают данный тезис, в связи с чем целесообразно определить роль и степень ответственности независимых директоров в корпоративном управлении.
\end{abstract}

Ключевые слова: Гражданское право, корпоративное право, корпоративное управление, независимый директор, акционерные общества.

\section{THE ROLE AND RESPONSIBILITY OF INDEPENDENT DIRECTORS IN THE CORPORATE GOVERNANCE SYSTEM}

\section{Galynina Lidiya Ivanovna Bibikov Alexander Ivanovich}

\begin{abstract}
The article attempts to analyze the problems of corporate governance that have arisen due to the fact that over the two decades to the present period, citizens have the impression that management decisions and fraud within the company can be eliminated by attracting independent directors. However, precedents in corporate practice around the world do not confirm this thesis, and therefore it is advisable to determine the role and degree of responsibility of independent directors in corporate governance.
\end{abstract}


Key words: Civil law, corporate law, corporate governance, independent director, joint-stock companies.

Независимый директор (в англоязычной терминологии - nonexecutive director, NED или independent director, ID) в компании это сторонний эксперт, формально не входящий в число высших менеджеров организации, а также не имеющий личной заинтересованности в этом бизнесе [1, с. 47].

Соответственно независимый директор - это важное звено принятия решений, он отвечает за контроль выполнения управленческих решений, внутренний аудит, внутренний контроль, а также риск-менеджмент.

На основании опыта функционирования института независимого директора в Российской Федерации и США можно сделать вывод, что независимые директора в составуправления компаний эффективно влияют на корпоративное управление в силу статуса внешней, независимой стороны, активно вовлеченной в операционные процессы компаний.

Статус независимости в данном случае имеет прямое отношение к конкретному обществу (сюда включаются все виды АО: открытие, закрытое, а также общества с ограниченным или дополнительным типом ответственности). Он считается действительным с момента избрания определенного лица в состав совета директоров и до заявления по поводу изменения статуса или сложения полномочий этого члена совета.

Для определения «признаков независимости», как рекомендуют отечественные и авторитетные зарубежные кодексы корпоративного управления (поведения), Правила применяют понятие «антикритериев». А именно предлагают считать, что член совета директоров не может быть независимым директором, если он связан:

1) с эмитентом;

2) с существенным акционером эмитента;

3) с существенным контрагентом эмитента;

4) с конкурентом эмитента;

5) с государством (Российской Федерацией, субъектом Российской Федерации) или муниципальным образованием.

При этом можно утверждать, что четвертый «антикритерий» новым Кодексом корпоративного управления, одобренным Правительством РФ 13 февраля 2014 г., не используется. Но при этом является обоснованным 
утверждение, что Кодекс сохранил статус рекомендательного акта, компании при разработке собственных критериев во внутрифирменных кодексах распоряжаются правом согласиться (или не согласиться) с логикой разработчиков институтов Биржи. Однако в случае желания компании разместить свои акции на Московской бирже, требования в отношении присутствия независимых директоров тем или иным образом должны соблюдаться.

На основании опыта функционирования института независимого директора в Российской Федерации и США можно сделать вывод, что независимые директора в составе управления компаний эффективно влияют на корпоративное управление в силу статуса внешней, независимой стороны, активно вовлеченной в операционные процессы компаний. [2, с. 5].

Американское законодательство в системном толковании норм Тhe Delaware Code и Investment Company Act of 1940, Sarbanes Oxley Act of 2002 устанавливает, что независимым может быть член исполнительного органа корпорации с соблюдением ряда следующих условий:

1) в течение последних двух финансовых лет не являлся членом исполнительного органа данного PJSC либо руководителем юридического департамента (in-house legal counsel);

2) не является учредителем или членом исполнительного органа аффилированной JSC (акционерного общества);

3) не является членом семьи или близким родственником одного из членов исполнительного органа данного PJSC;

4) не является лицом, заинтересованным в выстраивании инвестиционной стратегии корпорации в интересах третьих лиц;

5) в течение последних 6 месяцев не совершал финансовых операций от своего имени или через аффилированную корпорацию по приобретению доли в уставном капитале PJSC (call option transactions);

6) не является членом Комиссии по отбору кандидатов на позицию независимого директора (the Order Commission by the Board Directors) и не способен оказать влияние на принятие решения данной Комиссией;

7) не является кредитором данного PJSC по всем типам займа (loan) или лицом, имеющим коммерческий интерес в финансовой деятельности PJSC. 
Институт независимого директора был введен на добровольных началах в качестве меры эффективного корпоративного управления в США в 1950-х гг. [3, с. 1364].

В 2002 г. в Великобритании был опубликован Cadbury Committee Report, который стал отправной точкой для массового появления института независимого директора не только в англо-саксонской правовой системе, но и практически во всех развивающихся странах мира с относительно развитыми финансовыми системами (Россия, Индия, Китай, ЮАР, Бразилия). Указанный новый глобальный тренд в корпоративном управлении стал в большей или меньшей степени повсеместным явлением.

К наступлению 2016 г. большинство стран-членов Европейского Союза, а также почти все крупные азиатские юрисдикции уже сформировали свои правовые требования, применяемые к независимым директорам и советам директоров. На наднациональном уровне Принципы корпоративного управления ОЭСР, опубликованные в 2015 г., утвердили свои рекомендации, которых страны должны были придерживаться в формировании принципов корпоративного управления.

В первой половине двадцатого века модель корпоративного управления, доминировавшая в США, была основана на доктринах менеджеризма экономической теории, сфокусированной на роли профессионального менеджмента и акционерной собственности в крупной корпорации как динамичного и социально-однородного симбиоза институтов корпоративного управления.

Рассматривая не только корпоративное управление США, но и Китая, можно утверждать, что после нескольких десятилетий корпоративной реформы, корпоративное управление в Китае прошло путь совершенствования, как следствие укрепило нововведения. От предоставления фирмам большей автономии и полномочий на принятие решений до создания правовой структуры современного предприятия, Китай находится на новом этапе эволюции корпоративного управления. Продвигаясь вперед, теперь усилия будут сосредоточены на общесистемном наращивании потенциала, включая дополнительные международные стандарты там, где в этом есть смысл и обоснованность, оставаясь гибкими для учета местных нюансов. [4, с. 2]. 
В соответствии с этим целесообразно отметить, что для совершенствования функционирования института независимого директора в целом важно учитывать следующие факторы:

Учет международных стандартов корпоративного управления;

Влияние местного и локального законодательства на ведение корпоративного управления.

С теоретической точки зрения, введение института независимого директора в корпорациях указанных стран привело к улучшению системы корпоративного управления в средних и крупных корпорациях. [5, с. 50].

Однако на практике проблемы особенностей деятельности независимых директоров в публичных компаниях, государственных предприятиях требуют дальнейших теоретических исследований, при изучении судебных решений.

Проверки их функционирования в правовой действительности, с применением различных существующих в мире теоретических подходов и критериев отбора модели дальнейшего развития системы корпоративного управления в России и США.

\section{Список литературы}

1. Магдалинская Ю.В. Особенности правового статуса института независимого директора в законодательных системах США и России // Вопросы российского и международного права. 2018. Том 7 № 1А. с. 42-51.

2. Письмо Банка России от 10.04.2014 № 06-52/2463 «О Кодексе корпоративного управления» // Вестник Банка России. 2014. № 40.

3. Berle A.A., Jr. (1932) For whom corporate managers are trustees: a note. Harvard law review. N 45. p.p. 1365-1372.

4. Gallo J. China news: a note. News on materials caixinglobal.com. PRC.today. 10.09.2020. p.p. 1-4.

5. Филатов В.В., Шемякина М.С., Горина Т.В., Зеер Е.В. Современные проблемы корпоративного управления ПАО НК «Роснефть» // Экономические исследования. с. 48-55. 